\title{
Hypogammaglobulinaemia associated with long term, low dose steroid therapy
}

\author{
R.J.E. Lee ${ }^{1}$ and A.C. Fay ${ }^{2}$ \\ ${ }^{1}$ Department of Medicine, The Queen's University of Belfast, and ${ }^{2}$ Department of Microbiology and \\ Immunobiology, Royal Victoria Hospital, Belfast, UK.
}

\begin{abstract}
Summary: Repeated pneumonia and hypogammaglobulinaemia was associated with long term low dose steroid therapy. Clinical improvement with restoration of antibody levels followed substitution of aerosol for oral therapy.
\end{abstract}

\section{Introduction}

It is known that systemic corticosteroid therapy can cause immunosuppression. This is predominantly due to inhibition of T-cell function, causing a reduction in the cell-mediated immune response. Conventional doses of steroids do not usually cause hypogammaglobulinaemia.

\section{Case report}

A 50 year old heterosexual car mechanic was admitted with an infective exacerbation of chronic wheezy bronchitis. He had been asthmatic since childhood, and for three years previously had been taking $7.5 \mathrm{mg}$ enteric coated prednisone in addition to regular bronchodilator therapy. There had been a recent deterioration in his chest condition, with five admissions to hospital in the previous year because of infective exacerbations.

On this admission Haemophilus influenzae was cultured in the sputum. He was treated in the usual way, and his steroid dose was temporarily increased to $30 \mathrm{mg} /$ day, tapering down to $5 \mathrm{mg}$ /day over 4 weeks. Serum analysed $4 \mathrm{~d}$ after this increase showed a low normal protein at $65 \mathrm{~g} / 1$ (normal $59-80 \mathrm{~g} / \mathrm{l}$ ) and a raised albumin $45 \mathrm{~g} / 1$ (normal $31-43 \mathrm{~g} / \mathrm{l}$ ). The immunoglobulins were IgG $2.02 \mathrm{~g} / 1$ (normal $5.0-16.0 \mathrm{~g} / \mathrm{l}$ ), IgA $1.52 \mathrm{~g} / 1$ (normal $1.25-4.25 \mathrm{~g} / \mathrm{l}$ ) and $\operatorname{IgM} 0.74 \mathrm{~g} / 1$ (normal 0.4-2.0 g/l).

There was no evidence of lymphoproliferative or other disease causing secondary antibody deficiency.

Further investigation of the patient's immune sys-

Correspondence: R.J.E.Lee, M.B., M.R.C.P., Department of Medicine, Queen's University of Belfast, Institute of Clinical Science, Grosvenor Road, Belfast BT12 6BJ, UK. Accepted: 19 September 1984 tem showed that his total lymphocyte count was normal $\left(1.98 \times 10^{9} / 1\right)$, as was the number of $\mathrm{sIg}^{+}$cells $\left(0.13 \times 10^{9} / 1\right), \mathrm{OKT}^{+}$cells $\left(1.29 \times 10^{9} / 1\right), \mathrm{OKT}^{+}$ cells $\left(0.79 \times 10^{9} / 1\right), \mathrm{OKT}^{+}$. cells $\left(0.65 \times 10^{9} / 1\right)$, and esterase $^{+}$cells $\left(0.73 \times 10^{9} / 1\right)$. The surface isotypes of the $\mathrm{sIg}^{+}$cells showed a normal distribution. There was a normal response of his lymphocytes to PHA stimulation. These results are in keeping with a diagnosis either of late onset hypogammaglobulinaemia (Asherson \& Webster, 1980), or a drug induced phenomenon (Ten Berge et al., 1984). When the patient's peripheral B cells were used in a colony-forming assay by culturing in soft agar, the number of colonies produced was normal. This is in contrast to our experience with cases of true late onset hypogammaglobulinaemia, where the number of B cell colonyforming cells in the peripheral blood is dramatically reduced (Fay, unpublished data).

A second admission 4 weeks later was precipitated by acute respiratory infection. The patient was now on $5 \mathrm{mg}$ prednisone daily. Immunoglobulins were again low - IgG $3.46 \mathrm{~g} / \mathrm{l}, \mathrm{IgA} 1.00 \mathrm{~g} / \mathrm{l}$ and IgM $0.66 \mathrm{~g} / \mathrm{l}$.

Oral therapy was withdrawn and replaced with beclomethasone aerosol, two inhalations every $6 \mathrm{~h}$. IgA returned to normal within 1 week and IgG by 2 weeks. Now, 6 months later, the immunoglobulins remain in the normal range. The patient's chest condition is stable, with one infective episode only during this time.

\section{Discussion}

Systemic corticosteroids cause lymphocytopenia and $T$ cells are affected more than B cells (Fauci et al., 1976). Interference with B cell function is rarely sufficient to cause a reduction in gammaglobulin levels 
(Lachman \& Peters, 1982), although 'supra pharmacological' doses i.e. $96 \mathrm{mg}$ prednisone for 3 or $5 \mathrm{~d}$, will cause this (Butler \& Rossen, 1973). The mechanisms involved are complex and controversial. Butler \& Rossen suggested reduced synthesis and increased catabolism of antibody. More recently, Galanaud et al. (1983) have proposed that steroids potentiate prostaglandin-mediated inhibition of B cell function.

One explanation for the low antibody levels in this case might be that the patient was taking much larger

\section{References}

ASHERSON, G.L. \& WEBSTER, A.D.B. (1980). In Diagnosis and Treatment of Immunodeficiency Diseases, 1st Edition, pp. 37-61. Blackwell Scientific Publications: Oxford.

BUTLER, W.T. \& ROSSEN, R.D. (1973). Effects of corticosteroids on immunity in man. I. Decreased serum IgG concentration caused by 3 or 5 days of high doses of methylprednisolone. Journal of Clinical Investigation, 52, 2629.

FAUCI, A.S., DALE, D.C. \& BALOW, J.E. (1976). Corticosteroid therapy: mechanisms of action and clinical considerations. Annals of Internal Medicine, 84, 304.

GALANAUD, P., CREVON, M.C., EMILIE, D. \& ABELLA, A. doses of steroid than he admitted. We believe the patient was genuine and cannot accept that theory.

Whatever the mechanism, the rapid return of the IgA and IgG levels to normal after withdrawal of oral steroid suggests a direct drug induced inhibition of antibody synthesis. This supports the view that this is a case of clinically important hypogammaglobulinaemia caused by long term low dose steroid therapy. Perhaps an increased awareness of this possibility will result in similar cases being found.

(1983). Effect of hydrocortisone on the in vitro human antibody response interaction with monocytes and prostaglandins. Clinical Immunology and Immunopathology, 29, 403.

LACHMAN, P.J. \& PETERS, D.K. (1982). In Clinical Aspects of Immunology, IVth Edition, p.516. Blackwell Scientific Publications: Oxford.

TEN BERGE, R.J.M., SAUERWEIN, H.P., YONG, S.L. \& SCHELLEKENS, P.T.H.A. (1984). Administration of prednisolone in vivo affects the ratio of OKT4/OKT8 and the LDH-Isoenzyme pattern of human T lymphocytes. Clinical Immunology and Immunopathology, 30, 91 . 